\title{
Vascular Endothelial Growth Factor Receptor 2 Measurement
}

National Cancer Institute

\section{Source}

National Cancer Institute. Vascular Endothelial Growth Factor Receptor 2 Measurement. NCI Thesaurus. Code C156527.

The determination of the amount of vascular endothelial growth factor receptor 2 present in a sample. 